\title{
Detection of Pneumocystis in lungs of bats from Brazil by PCR amplification 1
}

\author{
Edna Maria Cavallini Sanches ${ }^{2,3,4^{*}}$, Susi M. Pacheco ${ }^{5}$, Alison S. Cericatto ${ }^{6}$, \\ Rosane M. Melo ${ }^{6}$, Edson Molleta Colodel ${ }^{3}$, Jennifer Hummel ${ }^{2}$, Simone P. \\ Bianchi $^{2}$, Andréia Spanamberg ${ }^{2}$, Janio M. Santurio ${ }^{7}$ and Laerte Ferreiro ${ }^{2}$
}

\begin{abstract}
Cavallini Sanches E.M., Pacheco S.M., Cericatto A.S., Melo R.M., Colodel E.M., Hummel J., Bianchi S.P., Spanamberg A., Santurio J.M. \& Ferreiro L. 2009. Detection of Pneumocystis in lungs of bats from Brazil by PCR amplification. Pesquisa Veterinária Brasileira 29(6):469-473. Setor de Micologia Veterinária, Faculdade de Veterinária, Universidade Federal do Rio Grande do Sul, Av. Bento Gonçalves 9090, Porto Alegre, RS 90540-000, Brazil. E-mail: cavallini.sanches@ ufrgs.br

Pneumocystis has been isolated from a wide range of unrelated mammalian hosts, including humans, domestic and wild animals. It has been demonstrated that the genome of Pneumocystis of one host differs markedly from that of other hosts. Also, variation in the chromosome and DNA sequence of Pneumocystis within a single host species has been observed. Since information about the occurrence and nature of infections in wild animals is still limited, the objective of this work was to detect the presence of Pneumocystis sp. in lungs of bats from two states from Brazil by Nested-PCR amplification. The bats, captured in caves and in urban areas, were obtained from the Program of Rabies Control of two States in Brazil, Mato Grosso and Rio Grande do Sul, located in the Mid-Western and Southern regions of the country, respectively. DNAs were extracted from 102 lung tissues and screened for Pneumocystis by nested PCR at the mtLSU rRNA gene and small subunit of mitochondrial ribosomal RNA ( $m$ tSSU $r R N A$ ). Gene amplification was performed using the $m t L S U$ rRNA, the primer set pAZ102H - pAZ102E and pAZ102X - pAZY, and the mtSSU rRNA primer set pAZ102 10FRI - pAZ102 10R-RI and pAZ102 13RI - pAZ102 14RI. The most frequent bats were Tadarida brasiliensis (25), Desmodus rotundus (20), and Nyctinomops laticaudatus (19). Pneumocystis was more prevalent in the species Nyctinomops laticaudatus (26.3\% $=5 / 19)$, Tadarida brasiliensis $(24 \%=6 / 25)$, and Desmodus rotundus $(20 \%=4 / 20)$. Besides these species, Pneumocystis also was detected in lungs from Molossus molossus (1/11, 9.1\%), Artibeus fimbriatus (1/1, 100\%), Sturnira lilium (1/3, $33.3 \%)$, Myotis levis (2/3, 66.7\%) and Diphylla ecaudata (1/2, 50\%). PCR products which could indicate the presence of Pneumocystis (21.56\%) were identified in DNA samples obtained from 8 out of 16 classified species from both states ( 5 bats were not identified). This is the first report of detection of Pneumocystis in bats from Brazil.
\end{abstract}

INDEX TERMS: Pneumocystis sp., bats, Nested-PCR.

\footnotetext{
${ }^{1}$ Received on October 6, 2008.

Accepted for publication on April 9, 2009.

2 Setor de Micologia Veterinária, Faculdade de Veterinária, UFRGS, Av. Bento Gonçalves 9090, Porto Alegre, RS 90540-000, Brazil. *Corresponding author: cavallini.sanches@ufrgs.br

${ }^{3}$ Universidade Federal de Mato Grosso (UFMT), Av. Fernando Côrrea s/n, Coxipó, Cuiabá, MT 78060-900, Brazil.

${ }^{4}$ Secretaria de Saúde de Mato Grosso, Centro Político Administrativo (CPA), Palácio Paiaguás, Bloco 5, Cuiabá, MT 78050-970.
}

\footnotetext{
${ }^{5}$ Instituto Sauver, Av. Pernambuco 26231, Sala 404, Porto Alegre, RS 90240-005, Brazil.

${ }^{6}$ Instituto de Defesa Agropecuária do Estado de Mato Grosso (LASA/ INDEA), Av. B s/n, Edifício Ceres, ㄴo andar, Centro Político Administrativo (CPA), Cuiabá, MT 78050-070.

${ }^{7}$ Laboratório de Pesquisas Micológicas (LAPEMI), Universidade Federal de Santa Maria (UFSM), Av. Roraima 1000, Cidade Universitária, Bairro Camobi, Santa Maria, RS 97105-900, Brazil.
} 
RESUMO.- [Detecção de Pneumocystis em pulmões de morcegos no Brasil por Nested-PCR.] Pneumocystis tem sido isolado de uma grande variedade de hospedeiros mamíferos, incluindo humanos, animais domésticos e selvagens. Tem se demonstrado que o genoma do Pneumocystis de um hospedeiro difere marcadamente do de outros, assim como há variação no cromossomo e na seqüência de DNA dentro de uma única espécie de hospedeiro. Sabendo que a informação da ocorrência e natureza da infecção em animais silvestres ainda é limitada, o objetivo do trabalho foi detectar, por Nested-PCR, a presença de Pneumocystis sp. em pulmões de diferentes espécies de morcegos de dois estados do Brasil. Estes mamíferos voadores foram capturados em cavernas, áreas florestadas, de campo e urbanas pelo Programa de Controle da Raiva do Mato Grosso (região Centro-Oeste) e do Instituto de Pesquisas Veterinárias Desidério Finamor (RS) e Instituto Sauver no Rio Grande do Sul (região Sul). Os DNAs foram extraídos de 102 pulmões e realizado Nested-PCR utilizando os primers pAZ102H-pAZ102E e pAZ102X/R1pAZY/R1 para amplificação do gene mtLSU-rRNA, e pAZ102 10F-RI - pAZ102 10R-RI e pAZ102 13-RI - pAZ14$\mathrm{RI}$ para amplificação do gene $m t S S U-r R N A$. As espécies mais freqüentes foram Tadarida brasiliensis (25), Desmodus rotundus (20) e Nyctinomops laticaudatus (19). Pneumocystis foi detectado com maior prevalência nas Nyctinomops laticaudatus $(26,3 \%=5 / 19)$, Tadarida brasiliensis $(24 \%=$ $6 / 25)$ e Desmodus rotundus $(20 \%=4 / 20)$. Além destas espécies, Pneumocystis foi também detectado nos pulmões de Molossus molossus (1/11, 9,1\%), Artibeus fimbriatus (1/ $1,100 \%)$, Sturnira lilium (1/3, 33\%), Myotis levis (2/3, 66,7\%) e Diphylla ecaudata (1/2, 50\%). Os produtos de PCR indicaram a presença de Pneumocystis (21.56\%) em amostras obtidas de 8 das 16 espécies classificadas para ambos os estados (cinco morcegos não foram classificados). Este é o primeiro registro de detecção de Pneumocystis em morcegos no Brasil.

TERMOS DE INDEXAÇÃO: Pneumocystis sp., bats, NestedPCR.

\section{INTRODUCTION}

Pneumocystosis is the disease caused by infection with Pneumocystis sp., irrespective of species and host. The host species is usually identified or implicated because of the species specificity of Pneumocystis spp (Frenkel 1999). Members of the genus Pneumocystis exhibit strict host specificity with at least one distinct species resident in the lungs of every mammalian host examined for its presence (Cushion 1998, Icenhour et al. 2006). This organism is considered an opportunistic pathogen, and causes a kind of pneumonia which may be lethal if the host reaches a state (Frenkel 1999). Pneumocystis pneumonia is characterized by intense neutrophilic lung inflammation associated with diffuse alveolar damage, gas exchange impairment and respiratory failure (Wright et al. 1999, Beck et al 2001).

The genus Pneumocytis is complex, containing many species of unusual, ascomyceteous yeasts, each of which can colonize the lungs of a different mammal (Stringer 2002). Pneumocystis spp infection has been reported in many mammalian hosts, such as in animals with acquired immunodeficiency or malnourishment, including foals (Perryman et al. 1978, Marrs 1987, Ewing et al. 1994, Peters et al. 1994b, Jensen et al. 2001), piglets (Bille-Hansen 1990, Kondo et al. 1993, Christensen 1996, Wakefield et al. 1997, Ramos-Vara et al. 1998, Jensen et al. 2001, Cavallini Sanches et al. 2006, 2007), dogs (Farrow et al. 1972, Hagiwara et al. 2001), cats (Yuezhong et al. 1996), monkeys (Durand-Joly et al. 2000, Demanche et al. 2001), shrews (Peters et al. 1994a, Laakonen and Sukura 1997), rabbits (Guillot et al. 1999, Dei-Cas et al. 2006), ferrets (Banerji et al. 1994), rats (Cushion 2004), and bats (Guillot et al. 2001, Akabar et al. 2008). Morphologic, antigenic and genetic differences can be detected across isolates of Pneumocystis extracted from the infected lungs of different mammalian host species (Eddind et al. 1992, Banerji et al. 1995, Mazars et al. 1995, Cushion 1998). Studies conducted in the past ten years have revealed that the genus Pneumocystis contains many distinct organisms. Differences have been observed for their cell surfaces, the conditions required for their growth, and their genomes. The genetic and functional diversity exhibited by these organisms indicates that Pneumocystis contains more than one species (Keely et al. 2003, Cushion 2004). Controversy surrounds these issues because Pneumocystis cannot be cultured, and mating experiments cannot be performed (Keely et al. 2003). However, the development of a molecular typing method for the uncultivable fungus Pneumocystis is described, and researchers have devised typing methods that rely on the amplification by PCR of variable regions of the genome, followed by the detection of the polymorphisms using DNA sequencing or various gel-based techniques (Hauser 2004). The degree of sequence variation seen between several gene orthologues suggested that DNA could be utilized to diagnose Pneumocystis species (Keely et al. 2003). The purpose of this article was to determine the prevalence of Pneumocystis DNA in bats captured in caves and in urban areas, from the Program of Rabies Control from Mato Grosso and Rio Grande do Sul, Brazil.

\section{MATERIALS AND METHODS}

Animals. The bats, captured in caves, forests, and urban areas, were obtained from the Program of Rabies Control of two States in Brazil, Mato Grosso and research institutions of Rio Grande do Sul, located respectively in the Mid-Western and Southern regions of the country. The bats from the state of Mato Grosso were provided by Instituto de Defesa Agropecuária do Estado do Mato Grosso (INDEA/MT) and Laboratório de Apoio à Saúde Animal (LASA), while the bats from the state of Rio Grande do Sul were offered by the Instituto de Pesquisas Veterinárias Desidério Finamor and by the Instituto Sauver. The bats were captured by these same institutions, according to the guidelines in the rabies control manual for herbivores, standardized by the Ministério da Agricultura e Pecuária (www.agricultura.gov.br/pls/portal/docs/page/mapa/programas/ 
area_animal/CRHE/PNCRH/MT_Para_controle_da_ raivaherbivoros_o.PDF). Bats were captured according to the protocol using mist nets measuring $5-12 \mathrm{~m}$ length and $1.5-5.0 \mathrm{~m}$ in height. Nets placed outside caves and dens were used to capture bats when leaving these diurnal shelters, and hand nets were employed to capture the animals at the colonies. Gauntlets and $30 \mathrm{~cm}$ tongs were used when capturing bats in roofs, in most cases. For roofs over $30 \mathrm{~m}$ in height, hand nets were used (Pacheco 2004). The bats thus captured were placed in cotton bags to prevent injury and stress (as defined in CFMV, law $51517 / 68,23 / 10 / 1968)$, in the presence of capture teams of the organs mentioned, formed by veterinaries, biologists and skilled technicians. The specimens that died were placed in sterilized plastic bags and frozen. These bats were thawed only at the moment when lungs and liver were excised in the Laboratório de Micologia, Faculdade de Veterinária, UFRGS.

The present study was evaluated by the ethics committees of CNPq and Fundação de Amparo à Pesquisa de Mato Grosso (FAPEMAT), which provided the financial grants to this research.

Pneumocystis DNA extraction and PCR. A small part (250mg) of the lung tissue was finely minced, homogenized by crushing and analyzed using the Kit Qiagen (Dneasy ${ }^{\mathrm{TM}}$ tissue Kit, Qiagen, Courtaboeuf, France). DNA was extracted from 102 lung tissues of bats and the presence of Pneumocystis DNA was determined by nested PCR at the mLLU rRNA gene and small subunit of mitochondrial ribosomal RNA ( $m$ tSSU-rRNA). For gene amplification ( $m t L S U$ rRNA), the primers sets pAZ102H-pAZ102E and $p A Z 102 X / R 1-p A Z Y / R 1$ were used. Thermocycling conditions for the first PCR round were as follows: each cycle consisted of denaturation for $1.5 \mathrm{~min}$ at $94^{\circ} \mathrm{C}$, annealing for $1.5 \mathrm{~min}$ at $55^{\circ} \mathrm{C}$, and extension for $2 \mathrm{~min}$ at $72^{\circ} \mathrm{C}$; 40 cycles were included in the protocol. The second PCR round was performed with the primer pair pAZY/R1 and pAZX/R1. Ten amplification cycles were carried out at $94^{\circ} \mathrm{C}$ for $1.5 \mathrm{~min}, 55^{\circ} \mathrm{C}$ for $1.5 \mathrm{~min}$, and $72^{\circ} \mathrm{C}$ for $2 \mathrm{~min}$, followed by 30 cycles at $94^{\circ} \mathrm{C}$ for $1.5 \mathrm{~min}, 63^{\circ} \mathrm{C}$ for $1.5 \mathrm{~min}$, and

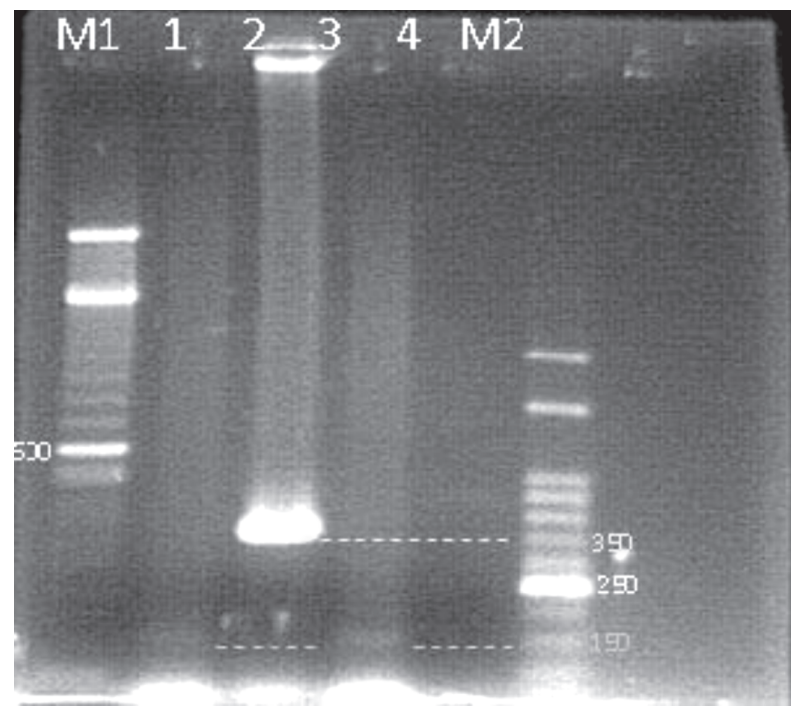

Fig.1. Polymerase chain reaction (PCR) products of DNA extracted from bat lungs infected with Pneumocystis. A nested PCR protocol was used to amplify a fragment of the Pneumocystis mtLSU rRNA gene (Lanes1,3) and mtSSU rRNA gene (Lane 2). Lane 4 negative control (water), M1, markers (100-bp ladder) and M2 (50-bp ladder). $72^{\circ} \mathrm{C}$ for $2 \mathrm{~min}$. Expected product sizes were approximately 150 bp (Fig.1) for the second PCR round.

For gene amplification ( $m$ tSSU $r R N A$ ), the primers sets pAZ102 10F-RI - pAZ102 10R-RI and pAZ102 13-RI - pAZ14$\mathrm{RI}$ were used. Thermocycling conditions for the first PCR round were as follows: each cycle consisted of denaturation for $1.5 \mathrm{~min}$ at $94 \mathrm{C}$, annealing for $1.5 \mathrm{~min}$ at $55^{\circ} \mathrm{C}$, and extension for $2 \mathrm{~min}$ at $72^{\circ} \mathrm{C}$; 40 cycles were included in the protocol. The second PCR round was performed with the primer pair pAZ102 13-RI - pAZ14RI. Ten amplification cycles were carried out at $94 \mathrm{C}$ for $1.5 \mathrm{~min}$, $52^{\circ} \mathrm{C}$ for $1.5 \mathrm{~min}$, and $72^{\circ} \mathrm{C}$ for $2 \mathrm{~min}$, followed by 30 cycles at $94^{\circ} \mathrm{C}$ for $1.5 \mathrm{~min}, 63^{\circ} \mathrm{C}$ for $1.5 \mathrm{~min}$, and $72^{\circ} \mathrm{C}$ for $2 \mathrm{~min}$. Expected product sizes were approximately $350 \mathrm{bp}$ for both the first and second PCR rounds (Fig.1).

\section{RESULTS}

The most frequent bat species were Tadarida brasiliensis (25), Desmodus rotundus (20), and Nyctinomops laticaudatus (19). Pneumocystis was more prevalent in the species Nyctinomops laticaudatus $(26.3 \%=5 / 19)$, Tadarida brasiliensis $(24.0 \%=6 / 25)$ and Desmodus rotundus $(20.0 \%=4 / 20)$. Besides these species, Pneumocystis was also detected in lungs from Molossus molossus (1/11), Artibeus fimbriatus (1/1, 100\%), Sturnira lilium (1/3, 33\%), Myotis levis (2/3, 66,7\%) and Diphylla ecaudata (1/2, 50\%). PCR products of which could indicate the presence of Pneumocystis (21.56\%) were identified DNA in samples obtained from 8 out of 16 classified species from both states ( 5 bats were not identified). The prevalence between wild and urban bats was (25.5\% [13/ 51] versus $17.5 \%$ [7/40] respectively). Eleven bats were not identified for their origin.

\section{DISCUSSION}

Several PCR assays have been developed in the past 15 years. PCR tool revealed to be highly efficient in detecting Pneumocystis DNA in lung samples from domestic or wild mammals (Mazars et al 1997, Peters at al 1994), as well as in the air (Bartlett et al. 1997, Peters 1996) or water in the environment, and sequences of selected Pneumocystis-DNA amplified fragments are used to identify Pneumocystis species or genotypes (Casa-Nova-Cardiel \& Leibowitz 1997). In a review, Cushion listed more than 30 different mammals from disparate groups such as rodents, carnivores, ungulates, lagomorphs, primates, insectivores and marsupials (Cushion 1998). In 2001 Guillot et al. confirmed a coevolution process observed in Pneumocystis species from mammalian hosts. They compared mitochondrial large subunit (mtLSU) and small subunit (mtSSU) ribosomal RNA sequences of Pneumocystis organisms from 24 different host species representing the following major mammalian groups: primates (12 species), rodents ( 5 species), carnivores ( 3 species), chiropters (one species), lagomorphs (one species), marsupials (one species), and ungulates (one species). With regard to bats, in a recent study (Akabar et al 2008), it was reported $29 \%$ (38/131) of Pneumocystis carriage, being out of: 6 from 
French Guyana, 13 from France and 19 from Mexico. Our percentage of Pneumocystis (21.6\%) and the bat species were different from those reported in the study mentioned above. The prevalence of Pneumocystis between wild and urban bats in Brazil was 25.5\% (13/51) versus 17.5\% (7/ 40) respectively. The present study evaluates the presence of a pneumonia causal agent (Pneumocystis sp.) in Brazilian bats transmitted by the air, which promotes the dissemination inside a colony and placing at risk the development of the community. This is the first report to detect Pneumocystis in Brazilian bats, and afford to know the pathological impact on the lungs of these animals, the extension of the presence of the fungal agent in Chiroptera populations, the description of new species of the pathogen. Furthermore, the sequencing of Pneumocystis in bats could be associated within the French Guyana group and correlated with the phylogenetic analysis.

\section{REFERENCES}

Akabar H., Aliouat C.M., Derouiche S., Taylor M.L., Chabe M., CarretoBinaghi L.E., Courpon A., Aliouat E.M., Dei-Cas E. \& Demanche C. 2008. Prevalence of Pneumocystis in bats. X International Workshops on Opportunistic Protists (IWOP-10), Boston, Massachusetts, USA.

Banerji S., Lugli E.B. \& Wakefield A.E. 1994. Identification of two genetically distinct strains of Pneumocystis carinii in infected ferret lungs. J. Eukaryot. Microbiol. 41(5):73S.

Banerji S., Lugli E.B., Miller R.F. \& Wakefield A.E. 1995. Analysis of genetic diversity at the arom locus in isolates of Pneumocystis carinii. J. Eukaryot. Microbiol. 42:675-679.

Bartlett M.S., Vermund S.H., Jacobs E., Durant P.J., Shaw M.M., Smith J.W., Tang X., Lu J.J., Li B., Jin S. \& Lee C.H. 1997. Detection of Pneumocystis carinii DNA in air samples: Likely environmental risk to susceptible persons. J. Clin. Microbiol. 35:2511-2513.

Beck J.M., Rosen M.J. \& Peavy H.H. 2001. Pulmonary complications of HIV infection: Report of the fourth NHLBI workshop. Am. J. Respir. Crit. Care Med. 164:2120-2126.

Bille-Hansen V., Jorsal S.E., Henriksen S.A. \& Settnes O.P. 1990. Pneumocystis carinii pneumonia in Danish piglets. Vet. Rec. 20:407408.

Casanova-Cardiel L. \& Leibowitz M.J. 1997. Presence of Pneumocystis carinii DNA in pond water. J. Eukaryot. Microbiol., 44:28S.

Cavallini Sanches E.M., Borba M.R., Spanamberg A., Pescador C., Corbellini L.G., Ravazzolo A.P., Driemeier D. \& Ferreiro L. 2006. CoInfection of Pneumocystis carinii f. sp. suis and Porcine Circovirus-2 (PCV2) in pig lungs obtained from slaughterhouses in southern and midwestern regions of Brazil. J. Eukaryot. Microbiol. 53:S92-S93.

Cavallini Sanches E.M., Pescador C., Rozza D., Spanamberg A., Borba M.R., Ravazzolo A.P., Driemeier D., Guillot J. \& Ferreiro L. 2007. Detection of Pneumocystis spp. in lung samples from pigs in Brazil. Med. Mycol. 45:395-399.

Christensen C.B.V., Settnes O.P., Bille-Hansen V., Jorsal S.E., Henriksen S.A. \& Lundgren B. 1996. Pneumocystis carinii from pigs and humans are antigenically distinct. J. Med. Vet. Mycol. 34:431-433.

Cushion M. 1998. Pneumocystis carinii, p.654-683. In: Collier L., Balows A. \& Sussman M. (Eds), Topley and Wilson's Microbiology and Microbial Infections. Arnold and Oxford Press, New York.

Cushion M. 2004. Molecular and phenotypic description of Pneumocystis wakefieldiae sp. Nov., a new species in rats. Mycologia, 96:429439.

Dei-Cas E., Chabé M., Moukhlis R., Durand-Joly I., Aliouat E.M., Stringer J.R., Cushion M., Nöel C., Hoog G.S., Guillot J. \& Viscogliosi E. 2006.
Pneumocystis oryctolagi sp. nov., an uncultured fungus causing pneumonia in rabbits at weaning: Review of current knowledge, and description of a new taxon on genotypic, phylogenetic and phenotypic bases. FEMS Microbiol. Rev. 30:853-871.

Demanche C., Berthelemy M., Petit T., Polack B., Wakefield A.E., DeiCas E. \& Guillot J. 2001. Phylogeny of Pneumocystis carinii from 18 primate species confirms host specificity and suggests coevolution. J. Clin. Microbiol. 39:2126-2133.

Durand-Joly I., Wakefield A.E., Palmer R., Denis M., Creusy C., Fleurisse L., Ricard I., Gut J.P. \& Dei-Cas E. 2000. Ultrastructural and molecular characterization of Pneumocystis carinii isolated from a rhesus monkey (Macaca mulatta). Med. Mycol. 38:61-72.

Eddind T.D., Bartlett M.S., Weinberg G.A., Prah G.N. \& Smith J.W. 1992. The b-tubulin gene from rat and human isolates of Pneumocystis carinii. Mol. Microbiol. 6:3365-3373.

Ewing P.J., Cowell R.L., Tyler R.D., MacAllister C.G. \& Meintkoth J.H. 1994. Pneumocystis carinii pneumonia in foals. J. Am. Vet. Med. Assoc. 204:929-933.

Farrow B.R.H., Watson A.D., Hartley W.J. \& Huxtable C.R.R. 1972. Pneumocystis pneumonia in dog. J. Comp. Pathol. 82:447-453.

Frenkel J.K. 1999. Pneumocystis pneumonia, an immunodeficiencydependent disease (IDD): A critical historical overview. J. Eukaryot. Microbiol. 46:89S-92S.

Guillot J., Chevalier V., Queney G., Berthelemy M., Polack B., Lacube P., Roux P. \& Chermette R. 1999. Acquisition and biodiversity of Pneumocystis carinii in a colony of wild rabbits (Oryctolagus cuniculus). J. Eukaryot. Microbiol. 46:100S-101S.

Guillot J., Demanche C., Hugot J.P., Berthelemy M., Wakefield A.E., Dei-Cas E. \& Chermette R. 2001. Parallel phylogenies of Pneumocystis species and their mammalian hosts. J. Eukaryot. Microbiol. 47:113S$115 S$.

Hagiwara Y., Fujiwara S., Takai H., Ohno K., Masuda K., Furuta T., Nakayama H., Doi K. \& Tsujimoto H. 2001. Pneumocystis carinii pneumonia in a Cavalier King Charles Spaniel. J. Vet. Med. Sci. 63:349351.

Hauser P.M. 2004. The development of a typing method for an uncultivable microorganism: The example of Pneumocystis jirovecii. Infection, Genetics and Evolution 4:199-203.

Icenhour C.R., Arnold J., Medvedovic M. \& Cushion M.T. 2006. Competitive coexistence of two Pneumocystis species. Infection, Genetics and Evolution 6:177-186.

Jensen T.K., Boye M. \& Bille-Hansen V. 2001. Application of fluorescent In situ hybridization for specific diagnosis of Pneumocystis carinii pneumonia in foals and pigs. Vet. Pathol. 38:269-274.

Keely S.P., Fischer J.M. \& Stringer J.R. 2003. Evolution and Speciation of Pneumocystis. J. Eukaryot. Microbiol. 624-626.

Kondo H., Taguchi M., Abe N., Nogami Y., Yoshioka H. \& Ito M. 1993. Pathological changes in epidemic porcine Pneumocystis carinii pneumonia. J. Comp. Pathol. 108:206-268.

Laakonen J. \& Sukura A. 1997.Pneumocystis carinii of the common shrew, Sorex araneus, shows a discrete phenotype. J. Eukaryot. Microbiol. 44:117-121.

Marrs G.E. 1987. Pneumocystis carinii pneumonia in a Paso Fino colt. Vet. Med. 82:1172-1173.

Mazars E., Odberg-Ferragut C., Dei-Cas E., Fourmaux M.N., Aliouat E.M., Brun-Pascaud M., Mougeot G. \& Camus D. 1995. Polymorphism of the thymidylate synthase gene of Pneumocystis carinii from different host species. J. Eukaryot. Microbiol. 42:26-32.

Mazars E., Guyot K., Fourmaintraux S., Renaud F., Petavy F., Camus D. \& Dei-Cas E. 1997. Detection of Pneumocystis in European wild animals. J. Eukaryot. Microbiol. 44:39S.

Pacheco S.M. 2005. Técnicas de campo empregadas no estudo de quirópteros. Cadernos La Salle 1(1):193-205. 
Perryman L.E., Macguire T.C. \& Crawford T.B. 1978. Maintenance of foals with combined immunodeficiency: cause and control of secondary infections. Am. J. Vet. Res. 39:1043-1047.

Peters A.E. 1996. DNA sequences identical to Pneumocystis carinii $\mathrm{f}$. sp. carinii and Pneumocystis carinii f.sp. hominis in samples of air spora. J. Clin. Microbiol. 34:1754-1759.

Peters S.E., English K., Laakkonem J. \& Gurnell J. 1994a. DNA analysis of Pneumocystis carinii infecting Finnish and English shrews. J. Eukaryot. Microbiol. 41:108S.

Peters S., Wakefield A., Whitewell K. \& Hopkins J. 1994b. Pneumocystis carinii pneumonia in thoroughbred foals: Identification of a genetically distinct organism by DNA amplification. J. Clin. Microbiol. 32:213-216.

Ramos-Vara J.A., Lu J.J., da Silva A.J., Montone K.T., Pieniazek N.J., Lee C.H., Peres L., Steficek B.A., Dunstan R.W., Craft D. \& Watson G.L. 1998. Characterization of natural occurring Pneumocystis carinii pneumonia in pigs by histopathology, electron microscopy, in situ hybridization and PCR amplification. Histol. Histopathol. 13:129136

Stringer J.R. 2002. Pneumocystis. Int. J. Med. Microbiol. 292:391- 404. Wakefield A.E., Keely S.P., Stringer J.R., Christensen C.B.V., Ahrens P., Peters S.E., Bille-Hansen V., Henriksen S.A., Jorsal S.E. \& Settnes O.P. 1997. Identification of porcine Pneumocystis carinii as a genetically distinct organism by DNA amplification. APMIS: Acta Pathol. Microbiol. Immunol. Scandinavica 105:317-321.

Wright T. W. \& Gigliotti F. 1999. Immune-mediated inflammation directly pulmonary function, contributing to the pathogenesis of Pneumocystis carinii pneumonia impairs. J. Clin. Invest. 104:1307-1317

Yeuzhong Y., Li Z. \& Bapoing T. 1996. Pneumonia in cats caused by Pneumocystis carinii purified from mouse lungs. Vet. Parasitol. 61:171175 . 